
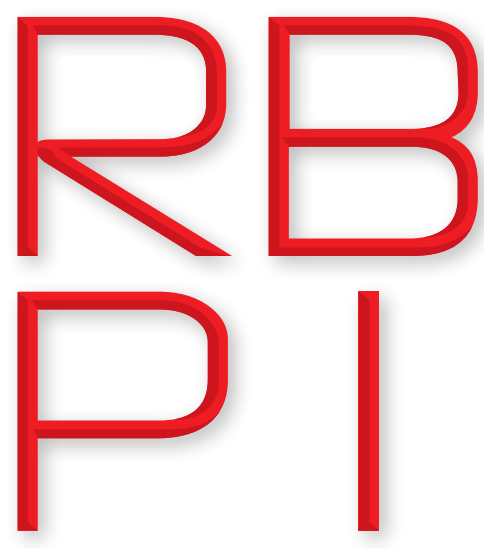

Revista Brasileira de Política Internacional ISSN 1983-3121

http://www.rbpi.info

\title{
Nicholas Onuf
}

Florida International University, Department of Politics and International Relations, Miami, United States (onufn@fiu.edu).

iD ORCID ID:

orcid.org/0000-0001-7212-8917

\section{Copyright:}

- This is an open-access article distributed under the terms of a Creative Commons Attribution License, which permits unrestricted use, distribution, and reproduction in any medium, provided that the original author and source are credited.

- Este é um artigo publicado em acesso aberto e distribuído sob os termos da Licença de Atribuição Creative Commons, que permite uso irrestrito, distribuição e reprodução em qualquer meio, desde que o autor e a fonte originais sejam creditados. 
Broadly speaking, this is a phenomenological conception of world as worlds, and one that I subscribe to myself.

There is, of course, a contrary claim, to the effect that there is only one world - the real world consisting of all things. Most of us are philosophical realists, for whom this claim seems indisputably right. In such a world, no society (with the possible exception of some huntergatherer societies) is ever wholly self-contained; all things in the world are caught up in a web of (causal, functional, constitutive) relations. This is an Aristotelian formula-every whole is a part of some larger whole. We who live in what we call, somewhat paradoxically, the modern or Western world depart from this formula when we insist that the world we live in is the only world there is - the sum of all things.

Indeed, we have it both ways. There is our objectively discernible, subjectively valorized modern world. There is another objectively discernible world of many worlds, or, as we are inclined to say, the rest of the world. Taken together, these two worlds-the modern world and the rest of the world-constitute an ostensible objective reality (ostensibly objective, ostensibly real) we also call the earth, planet or globe.

Here I am concerned with the three worlds that members of the modern world think they see: our world, the rest of the world, and the world as the largest possible whole. I am also concerned with the possibility of a fourth world. This is not the world so many of us see at hand-one in which, thanks to globalization, all has become modern, or indeed, postmodern. I rather doubt that tendencies already manifest in the modern world will result in any such outcome.

Instead, I foresee a fourth world — a straitened world — coming about when global capitalism collapses in the next few decades, infrastructure undergoes irreversible deterioration, and immiseration engulfs what we moderns call the middle class. I expect these developments to precipitate large scale civil violence and perhaps major wars, all of which will help to accelerate the coming of the next world, a postmodern world that will in some respects resemble the world that came before. Some of you will find these claims shocking; others will notice that they have a Marxist provenience. All of you will recognize them to be a matter of conjecture; evidentiary support for them will be highly controversial. (I have held this position for many years; see Onuf 1984.)

\section{Many Theories/Four Theoretical Frameworks}

I take a theory to be an ensemble of related, abstractly stated propositions about some world. Taken together, these propositions purport to tell us about how that world works. Again I am using functional language that owes a great deal to Aristotle. You all are familiar with other ways of talking about theory, generally involving 'cause' as a mechanical metaphor rather than 'function' and 'constitution' as organic metaphors. 
If we assume that the workings of any society are hugely complex, as I do, then we are likely to formulate many theories that are, at best, only obscurely related to each other (whether causally, functionally or constitutively). In the circumstance, we are forced to rely on a small number of competing theoretical frameworks by which to arrange our theories (or merely theoretical hunches). We judge these frameworks by their apparent relevance, coherence and plausibility.

When we look at the modern world and ask how it works, four theoretical frameworks immediately present themselves. One grants priority to the system of nation-states. We students of International Relations (IR) usually call this framework Realism. A second framework is Liberalism (or, in IR, Liberal-Institutionalism); it emphasizes a system of values centered on individual autonomy, equality and freedom of choice. While Realism sees sovereign states engaged in perpetually hostile relations, Liberal-Institutionalism confers on states the values that Liberalism ascribes to human individuals in their social relations.

The third framework we in IR have tended to minimize, except when we talk, rather confusedly, about governmentality (too often, with a confused Foucault as a source of inspiration; see Foucault, 1978). It directs attention to the rational organization of daily life. The last framework is one I have already invoked. Its large concern is the way social functions are defined and divided as modern life has become ever more complex.

For many social theorists the organizational framework is indicatively modern. David Mitrany's work (1964) aside, IR has largely ignored the functional framework, which I take to be distinctively modernist ('form follows function'). If the proximate source of the organizational framework is Weber, the proximate source of the functional framework, which gave rise to structural-functionalism in anthropology, sociology and comparative politics, is Durkheim. What we in IR call Constructivism is a framework that draws selectively on all four frameworks, but mostly to qualify and contain the first framework by emphasizing the constitutive features of all social relations.

Now, it should be clear that moderns view modernity as a world apart. By convention, all those societies not modern are traditional. Some traditional societies may be highly bureaucratized (thereby exhibiting a degree of organizational and functional development only recently achieved by modern societies). They may sustain relations with neighbors that resemble 'the state of war' among modern nation-states, though generally with less evident institutionalization. (Imperial relations with neighbors are far more likely to be institutionalized.)

Most importantly, no traditional society seems to have developed the theory and practice of liberalism. I think this claim is substantially correct. It is the other side of the coin that bears inspection. Are modern societies liberal? Obviously not all, as the recent experience of several Asian societies makes utterly clear. Latin America is an ambiguous case, because there has been long exposure to liberal values and a robust sense of individualism. The larger question is this: Did liberalism prevail even in those few societies said to exemplify the triumph of the principle that all human beings are free and equal by nature? 
I have commented on this 'revolution' elsewhere (Onuf 2013a). Here I want to emphasize an often unstated implication of the claim that modern liberalism emerged from the momentous events of the late 18th century. Modern liberalism displaced and defeated the old regime of status-ordering; social standing ceased to determine the distribution of opportunities and rewards available to members of society. As an alternative formulation, appearances, always associated with rank, no longer mattered in the way that tradition says they must.

The point is important, so let me repeat myself. In principle, status no longer matters in the modern world. Individuals have been rendered equal in their social relations; organizations are free to serve 'rational' ends. In practice, actual modern societies work best when they suppress status and its corrupting effects. By contrast, traditional societies are always status-ordered.

I am skeptical that modern practices ever fully dispatched status as an ordering principle (Onuf 2005). I am convinced that the last three decades have seen a resurgence of status concerns among the members of modern societies, that these concerns have significantly affected the way modern societies actually work, and that the large cause of this tendency has been the downward trajectory of global capitalism in producing material welfare-a tendency most obvious in the United States. I should also point out, as some Realists have recognized, that the system of relations among states preceded modernity and has always exhibited a traditional preoccupation with status.

One conspicuous feature of the decline of global capitalism as a slow-motion crisis is the widening gap between the rich and the poor in modern societies. This sorry state of affairs is a harbinger of the next world - the straitened world to come. Local conditions may mask this development, but only in the short run. Long-term decline of global markets will adversely affect productive activity and distributive mechanisms in every corner of the globe. Insofar as capitalism is global in reach, there is no escaping the demise of liberal modernity.

\section{Many Rules/Four Ethical Systems}

Every society is saturated in rules. Many of those rules (I would call them instruction-rules) tell people how to conduct themselves (Onuf 1989, ch. 2). Often these rules are tacit, typically they are specific to that society, even if similar rules are found in other societies. In so-called traditional societies, these rules tend to be specific in another sense: they apply specifically and differentially to people whom the rules have already differentiated by rank, status, standing or social position (I use these words more or less interchangeably). In effect, each rule specifies a duty and a duty-holder at one and the same time.

Thus traditional societies are said to value honor and hospitality, which means that they have well-developed codes specifying honorable and hospitable conduct by reference to social position. While I have argued that such codes constitute an everyday ethics to be found in every society (Onuf 1998a), they would not seem to constitute an ethical system in any society, chiefly 
because ethic systems are generally said to make universal claims about acceptable or appropriate human conduct. By this criterion, the Ten Commandments constitute a stern code of conduct specific to God's chosen people (or, more specifically, to men as heads of households_or so I interpret the last two Commandments). That this code now applies to a huge community of believers does not make it contents universal; no logic or method by which to universalize these or any other rules is implied.

Much the same can be said of Confucian ethics. Many commentators suggest that ren or benevolence is roughly equivalent to virtue (excellence-see below). Associated with ren are more specific virtues, such as sincerity, loyalty and piety. In my view the resemblance is as misleading as it is intriguing. Fei Xiaotong has argued that ancient Chinese society never produced 'an all-encompassing ethical concept'; ren is simply 'a compilation of all the ethical qualities of private personal relationships' (1992: 75-6). These relationships are familial in the first instance, and family relations are inalterably asymmetric or status-ordered. According to Fei, their 'most important 'feature is certainly ke ji fu li (subdue the self and follow the rites)' (1992: 74). Where there are rites, there are rules-exquisitely detailed rules from which no deviation is tolerated.

One of the innovations of the modern world is precisely the idea that ethical conduct need not depend on an internalized set of rules. Instead ethical conduct depends on a general, rationally mandated procedure for discovering a few universal rules_rules applicable to humanity as a whole, rules that any reasonable person can satisfactorily apply to any possible situation. Two such ethical systems dominate modern thought. One is due to Kant, the other to Bentham.

The first, deontological ethics, grants autonomy to each of us-freedom to legislate for ourselves - and demands that we treat other as ends and not means to an end. The second, consequentialist ethics, grants us equality and demands we act so as achieve the greatest good for the greatest number of us. Liberals prefer the Kantian system and see it manifest in the promulgation of human rights. People working in organizational contexts prefer some version of Bentham's system and see it realized in the quest for efficiency and proportionality. In principle, the two systems are radically incompatible; in practice, most moderns are adept at switching from one to the other as circumstances require.

Neither of the two modern ethical system seems to fit modernist conditions, in which functional differentiation produces ever more specialized spheres of skilled activities. Functional compartments cut across modern organizational arrangements even as functionally skilled personnel appropriate those arrangements for internal use. Lacking an ethical system that suits a functionally fragmented world, we see an emphasis on professionalization. As we all know from personal experience, professionalization is effectuated through detailed codes of conduct highly reminiscent of traditional codes, which candidate-professionals internalize in the course of intensive training.

Focused on aesthetic matters, the postmodernist movement has generally ignored the social side of modernism and its ethical implications. As postmodernism provoked a more general 
critique of modernity and a concern with what comes after modernity's demise, postmodern scholars have articulated a third ethical system without being clear as to the continued relevance of modern ethical systems. Is general subject is the 'other.' In this context, they have seized on one feature of the modern world-displacement from one's homeland-as demanding a universally warranted response and finding that response in the traditional value of hospitality (also see Onuf 2013b). In my view, postmodern resistance to universal claims combined, oddly enough, with reliance on Kant's brief remarks on hospitality as a universal duty undercut any sense that postmodern ethics function systematically, either as an alternative to modern ethics or traditional codes of conduct.

There is, however, a candidate for a fourth ethical system. It goes back to Plato and Aristotle, and yet it has been subject to a significant revival in recent decades. Called virtue ethics, it is routinely juxtaposed to modern ethical systems because it locates the normative thrust of conduct in character and education, and not in rules, whether universal or local. Arguably it is an alternative to any kind of ethics. If instead we think that internalizing examples of, and exhortations about, desirable character traits is no different from internalizing rules, then any list of virtues constitutes a highly coded code of conduct. I am inclined toward the latter view myself.

Virtue ethics has a long association with Republicanism as a political theory episodically institutionalized in practice. Like virtue ethics, republican theory goes back to Plato and Aristotle-notwithstanding their many differences. Republicanism found its golden age in Rome, experienced a major revival in the Renaissance and Enlightenment, set the stage for Liberalism, and was then eclipsed by modern developments. Along with virtue ethics, republicanism has enjoyed a recent revival, if only in theory (Onuf 1998b, ch. 2; Onuf 2013c; note that I do not limit Republicanism to the currently fashionable 'neo-Roman' version associated with Pettit 1997 and Skinner 1998).

Virtue ethics has much to offer today's world of functional differentiation and even more as this world gives way to the next world of straitened circumstances. To see how this is so, I need to show how virtue ethics can be considered an ethical system, and not just a list of desirable character traits. Such a system by no means evident in Classical Greek texts. Cicero took us in the right direction, and Adam Smith pretty much got us there. Cicero and Smith were both republican thinkers with strong Stoic sympathies. By implication, Republicanism may also find a place in the next world. (I do not pursue this possibility here, but see Onuf 2013c.)

\section{Virtue Ethics/Four Cardinal Virtues}

Virtues are many. Yet four have assumed a canonical status. They are the cardinal virtues: wisdom and/or prudence, courage or bravery, justice, and temperance or moderation. Convention holds them to derive from Plato, who linked virtue to what translators anachronistically call 'class' (Republic, 427e, 435b). Rulers should be wise, warriors courageous, workers temperate (thus 
reflecting the rational, spirited and appetitive parts of the soul); together they constitute a just society. Thus it would seem that the virtues can only be unified in or by an ideal society-one that is perfectly just.

The Republic offers a social theory that is conspicuously status-ordered. While Plato had much to say about wisdom, he gave relatively little attention to virtue as such. Aristotle's social theory is less conspicuously (or perhaps more complexly) status-ordered than Plato's, and his treatment of virtue is far more extensive. For Aristotle, virtue (excellence, aretē) is simultaneously a disposition to seek excellence (faculty, capacity, potentiality, dunamis), an activity (energeia) or way of being excellent, and even the state (hexis) of excellence achieved and thus worthy of praise (Nicomachean Ethics 1109b30-1)_all fitting together in his teleological worldview. Virtue relies on deliberation and choice. There is, however, no direct sense of necessity or obligation attaching to virtue in any of these senses. Insofar as ethical conduct depends on rules, virtue ethics is not up to the job-unless knowing what is excellent implicitly depends on rules for evaluating conduct.

For Aristotle, virtue is a whole with many parts, or readily distinguishable virtues. In the Nicomachean Ethics, III-VI, he offered a laundry list of virtues. If the cardinal virtues have a 'unity' (as is often claimed), then they are, for Aristotle, unified only in the trivial sense that their presence in varying degrees, along with many other virtues, describes any individual human being's character. The cardinal virtues are not unified in such a way as to constitute a principle or generalizable standard of worth. Much less are they ordered as a set of principles such as is implied by the modern idea of an ethical system.

In Aristotle's laundry list of virtues, courage comes first, then temperance (sōphrosunē). Discussion of generosity, magnificence, and magnanimity follows. Only then did he turn to justice. Generosity, magnificence, and magnanimity apply disproportionately to high status individuals. Aristotle had much less to say about the 'homely' virtues of associated with people of lesser status (starting with women), such as fidelity, humility, modesty and thrift. Breaking with the logic of the four-virtue scheme, he treated 'virtues of character' and 'virtues of thought' separately. The latter include prudence and wisdom.

In Greek thought, natural goodness or well-being (eudaimonia) might serve as such a principle, but it is hard to formulate as such (rather than as a tendency or disposition) and little help in choosing a course of action when specific virtues from Aristotle's list point in different directions. Thus in practice choice would seem to be substantially situational or contingent. This sort of ethics has no compelling answer to the charge of relativism. In contrast, modern ethical systems insist that some few rules should be framed abstractly enough to be credibly universal, that is, applicable to humanity as a whole, thereby sidestepping the issue of depending on local, contingent rules. Hence the appeal of Kant's categorical, but strictly procedural imperative (act as if the maxim of your action were universal/a law of nature) or Bentham's utilitarian calculus (act so to maximize the greatest good for the greatest number). 
In Hellenistic Stoicism, discussion of ethics settled on the cardinal virtues and the claim that each virtue depends on the other three to be existentially and normatively complete. They constitute the ideal life lived according to nature. In this way of thinking, the cardinal virtues are analogous to the cardinal directions (north, east, south, west). North (wisdom) points to reason (logos), east (courage) to passion (pathos), south (justice) to lawful nature (phusis), and west (temperance) to the constraining features of society (nomos). Thus the wisdom-justice axis and the courage-temperance axis are intersecting binaries; at the point of intersection are human beings (anthrōpoi), in full possession of their faculties and pulled in all four directions at once. One must balance these tendencies, as circumstances require, to live well.

Implied is self-control (kratein) at the center of a ring of cardinal virtues. Aristotle had made the lack of self-control (typically translated 'incontinence') a central theme in his ethics (Nicomachean Ethics, VII), and this emphasis seems entirely consistent with our contemporary understanding of Stoicism. (I should register here my misgivings in using the term self so anachronistically.) It does not, however, unify the virtues and constitute virtue ethics as universalizable ethical system, unless we believe that self-control is all that matters_-as an end in itself that trumps all other ends.

Much influenced by Hellenistic Stoicism, Roman thinkers adopted the four-virtue scheme. Cicero's treatment in On Duties is exemplary. In this text, written as advice to his son, the virtues become duties (officia) together constituting honorable conduct. The correspondence between virtue and duty, and duty's relation to rules specifying duties, are not characteristic of classical Greek thought. The closest Greek equivalent to duty would seem to be kathekon, which the Stoics understood to mean 'appropriate action' (Cicero 1991, Notes on Translation, p. xlv). Given Cicero's belief in natural law, it follows that a status-order mandated by nature would assign normative weight to the virtues associated with rank or position in that status-order.

For Cicero, the cardinal duties are sapientia, not to be confused with prudentia (or 'knowledge of things that one should pursue and avoid,' On Duties, I, 153; Cicero 1991, p. 59), magnitudo animi, or greatness of spirit, iustitia, and decorum. While the cardinal virtues are 'bound together and interwoven' ( $\mathrm{I}, \mathrm{xv} ; \mathrm{p} .7$ ), they have no unity in themselves. Instead it is 'the power of reason' that 'unites one man to another' (I, xii; p. 6). Thus the fourth virtue is better translated as seemliness than as decorum (Cicero 1991, Notes on Translation, p. xlvi). As a virtue, decorum or seemliness is appropriate conduct in a given social arrangement, or being true to one's position or status in society. Notice the shift from temperance as a disposition offsetting passion to seemliness as a social concern. In Cicero's scheme, all four duties apply to all human beings but relatively; duty is the aggregate of duties; position correlates with the burden of duty.

While St Thomas made the cardinal virtues (virtutes cardinals)—prudentia, fortitudo, iustitia, temperantia - basic to Scholastic ethics (Summa theologica, I-II, Q. 61), he seems to have denied the normative thrust that Cicero gave them. Much influenced by Aristotle, St Thomas appealed 
instead to our capacity for reason. Notwithstanding his attempt to show how the four cardinal virtues are related in and through good conduct, they remain discrete. Joining them are the so-called 'theological virtues' of faith, hope, and charity, which are gifts of God's grace (Catechism of the Catholic Church, para. 1803-29; catechism and kathekon have the same Greek root).

If Christianity speaks to and for the oppressed, then faith, hope and charity might be construed as low-status counterparts to magnanimity, magnificence and generosity. In practice, the cardinal virtues apply chiefly to men and the theological virtues to women. The many virtues are not unified because God (or God's love or God's will) is already the source and meaning of unity. Thus the virtues join God's commands in guiding Christian conduct, but they do not in themselves constitute an ethical system of universal principles.

Ethics as virtuous conduct is a major concern in Humanist/Renaissance discourse. Machiavelli is only the most famous writer of that time to consider virtuous conduct-famous, of course, for disowning the Scholastic point of view. As a republican thinker, Machiavelli directed attention to virtú as 'grandezza dello anima' (Il Principe, VIII). More specifically, to avoid the contempt of his subjects, the prince 'should contrive [ingegnarsi, do one's best] that greatness, spiritness, gravity and strength [grandezza, animosità, gravità, fortezza] are recognized in his actions' (XIX; Machiavelli 1998, p. 72) Here, it seems, virtue is an ordered composite of the several virtues. Machiavelli's emphasis on spirit and spiritedness suggests a link to self-control, magnanimity and a sense of proportion, but not moderation.

Protestantism emphatically shifted emphasis from virtue to duty. Self-control conceptualized as conscience comes to the fore. John Milton, a republican Calvinist, here assuming the voice of God, offers a powerful example in Paradise Lost (1667), Book 3, lines 191-7:

To prayer, repentance, and obedience due, though but endevord with sincere intent, Mine eare shall not be slow, mine eye not shut. And I will place within them [human beings] as a guide my Umpire CONSCIENCE, whom if they will hear, light after light well us'd they shall attain, and to the end persisting, safe arrive.

What Max Weber called 'the Protestant ethic' resonates with a Stoic sense of duty-the virtues as duties, unified as one's vocation or calling:

The only way of living acceptably to God was not to surpass worldly morality in monastic asceticism, but solely through the fulfilment of the obligations imposed upon the individual by his position in the world [Lebensstellung]. That was his calling (Weber 1930, p. 80).

Let me emphasize: '...obligations imposed upon the individual by his position [Stellung] in the world.'

In early modern thought, Adam Smith articulated a distinctive ethical system in The Theory of Moral Sentiments (1759). Given Smith's reputation as father of liberalism, I should emphasize 
that he was indeed a republican thinker and no advocate of the principle of natural equality. In his view, social inequalities are given by nature:

The objects with which men in the different professions and states of life are conversant, being very different, and habituating them to very different passions, naturally form in them very different characters and manners. We expect in each rank and profession, a degree of those manners, which, experience has taught us, belong to it. But as in each species of things, we are particularly pleased with the middle conformation, which, in every part and feature, agrees most exactly with the general standard which nature seems to have established for things of that kind; so in each rank, or, if I may say so, in each species of men, we are particularly pleased, if they have neither too much, nor too little of the character which usually accompanies their particular condition and situation (V, ii, 5; Smith 1984, p. 202).

The Aristotelian emphasis on continence or self-control reveals itself in the Stoic counsel of equanimity. For Smith 'self-command' is central to ethical conduct, not to mention 'selfapprobation.'

The man of real constancy and firmness, the wise and just man who has been thoroughly bred in the great school of self-command, in the bustle and business of the world, exposed, perhaps, to the violence and injustice of faction, and to the hardships and hazards of war, maintains this control of his passive feelings upon all occasions; and whether in solitude or in society, wears nearly the same countenance, and is affected very nearly in the same manner (III, iii, 25; Smith 1984, p. 146).

The degree of the self-approbation with which every man, upon such occasions, surveys his own conduct, is higher or lower, exactly in proportion to the degree of self-command which is necessary in order to obtain that self-approbation (III, iii, 26; Smith 1984, p. 147).

For Smith and other early modern republicans, self-control is listening to one's conscience (the internalized, impartial observer). This is a stern demand but does not give the virtues any unity, or order one's duties, so as to guide conduct in every situation.

Instead we are guided by the admiration with which others' respond to our conduct. If we are vicious (as Aristotle insisted, every virtue has a contrary vice), then it is the contempt and indignation of others that guides us. Admiration, contempt and indignation are the social mechanisms for operationalizing Smith's ethical theory. Their force stems from our need to be praised.

The jurisdiction of the man within, is founded altogether in the desire of praiseworthiness, and in the aversion to blame-worthiness; in the desire of possessing those qualities, and performing those actions, which we love and admire in other people; and in the dread of possessing those qualities, and performing those actions, which we hate and despise in other people (III, ii, 32; Smith 1984, p. 131). 
I suggest that Smith accomplished something that none of his predecessors could in their quest to unify the cardinal virtues. By making self-control a human universal explained by our common need for praise and hinting at the normative consequences of praise and blame, he transformed virtue ethics into an ethical system. This system produces rules, which Cicero simply stipulated, but it does so in a way that we now attribute to customary practices. These rules may well instruct us individually to conduct ourselves as if individuality were a property of the collectivity and not ourselves. If we all respond to praise and blame more or less the same way, this pattern of responses duly acquires normative weight. Indeed it becomes a source of law_arguably its primary source (Kelsen 1961, pp. 110-15).

\section{Virtue Ethics Today/Four Pathologies}

As an ethical system, virtue ethics does not imply a unity of virtues even in the weak sense of a given set of virtues ordered by importance. Not only is priority relative to position in any society, discernible as such, but also to the conditions in which that society is obliged to operate. It is the one ethical system that takes every society to be status-ordered. Every status-order places everyone to whom it applies in a fixed position in relation to everyone else.

We visualize that order vertically, as an ascending (or descending) set of steps. For this arrangement we typically use the term rank. We also use for this term for the typical arrangement of offices in an organization; office often entails a corresponding social position (see below). Every one of us has a position in one or another status rank, of which we are then a member, on equal terms with everyone else holding that same rank. We know or find our position-our place, rank, standing or station in society-by reference to the titles, honors, privileges, liberties and immunities that 'society' has assigned to us. They may be ours by circumstance over which we have no control or we may be said to have earned them. They may or may not be revocable or indeed alienable. Exercising them may or may not degrade or enhance them.

The content of one's duties corresponds to social or worldly position. We can identify our duties first by constructing a check list of virtues (starting with the four cardinal virtues), and then by asking how those virtues, framed by reference to one's position and conditioned by circumstances, translates into duties. For convenience, those duties may be codified.

Presumably any reasonable person can do this (as indicated by the first of the cardinal virtues); everyone is doing it all the time. Self-control is taken for granted. Fulfilling our duties is virtuous, expected by all (that is, people in all positions) and backed by the positive sanction of admiration or negative sanction of disapproval experienced as shame.

As a general matter, those who have the least standing in any society have the fewest or least demanding duties. Everyone holds those in the highest positions to the highest standards, and we all know that this expectation is warranted. Those who have the highest positions in society have the most privilege as well as the greatest burden of duty. Privilege permits or creates 
opportunities for bad, vicious or corrupt behavior arising from lack of self-control. Some versions of republican theory takes corruption to be the great danger in the organization of politics, a danger liberals are disposed to overlook and powerless to combat.

Recall that virtue ethics, as an ethical system, does not order the virtues by normative weight. Yet it is possible to formulate some limited generalizations about the way particular societies rank the cardinal virtues (as against Plato's status-order for an ideally just society). Members of traditional societies will generally give priority to seemliness or propriety and to courage. In modern societies, wisdom (rationality) and justice are favored; courage and seemliness are seen as faintly irrational or atavistic. When societies are stable, justice and seemliness prevail (even when seemliness is not recognized for what it is); when times are turbulent, prudence and courage are valued more.

As the world as a whole slides into grinding poverty, massive inequity and chronic violence, deontological and consequentialist ethics will lose their appeal. Indeed, their natural constituencies will disappear. Functional compartmentalization will capture organizations, and loosely federal arrangements such as favored in republican theory may prevail in the best of circumstances. The nation may endure as an emotional anchor for depleted populations.

If any ethical system speaks to such a future, it can only be virtue ethics. Offering, as it does, different combinations of virtues for different situations, virtue ethics offers something in every situation short of complete social collapse. In some conspicuous situations, Machiavelli's greatness of spirit will trump the other virtues. In troubled times, prudence (and the perseverance it implies) will, in my opinion, win out more often than not. If status-orders stabilize locally, then the traditional preference for seemliness and courage may well prevail.

There are, however, four pathologies that I see already, and too often, in our allegedly modern yet status-ordered world. Decline is likely to aggravate them, in the process discrediting virtue ethics. Let me comment briefly on each. These pathologies are not peculiar to individuals. Corporate entities (nations, professions, functional organizations, cyber-communities, villages etc.) are readily afflicted.

Stasis. Modern thought holds that traditional societies are static-they resist change (and note the Classical Greek sense of stasis as strife-ridden). In the first instance, status orders are fixed in and by dense webs of rules; and one individual's social position is determined at birth; one's actions (for example, heroism) and events (for example, war) only exceptionally alter this social reality. I should point out that republican theorists from Aristotle to Machiavelli to the US founding fathers grappled with the issue of stasis by virtue of ascription. They argued that those who rule should be those whom nature has given the talents or capacities to rule: an aristocracy of merit. (See, for example, Thomas Jefferson's letter to John Adams, 28 October 1813, in Cappon 1959, pp. 387-92.)

Modern thinkers have always been skeptical that this republican solution to the problem of stasis actually ever works for long. Only if societies accept the principle of natural equality will merit find its reward and societies be ruled by those whom others take to have a talent for rule. 
Needless to say, modern liberals hold this principle dear. So do most moderns adept at life in a world of organizations, at least to the extent that they see merit rewarded in organizational settings.

Contrary to modern hopes, status-ordering may be less visible in modern circumstances, but it has never gone away. Successful organizations give rise to correlative status-orders. They tend to reward merit with higher status in the organization. Status based on achievement and duly rewarded is sticky the way status always is, gradually taking on the properties of ascription. Individuals with high status use that status to reward those to whom they ascribe various attractive, promising or useful traits rather than their achievements.

The same dynamic operates in the professions, in which status ordering has always dominated. Even as the professions have organized around meritorious performance, they have reinforced that static properties of an ascriptive status-order. World of scholarship is a telling example. In my view, there is no solution to this pathology, which can only worsen as this world transitions to the next world.

To put the point in the broadest possible terms: Virtue is its own reward. This is what my Yankee relatives used to say (evidently quoting the Roman poet Claudius Claudianus). Better to say: Self-control actualized as virtuous conduct and the praise that such conduct brings are reward enough. But are they? As an ethical system, virtue ethics is flawed to the extent that this not the case for most people most of the time.

Machismo. Modern thought holds that traditional societies give undue emphasis to honor or respect. Their members respond to insults and even more subtle signs of disrespect with a fury out of proportion to the 'slight' (as this very metaphor suggests). Insofar as respect attaches to one's social position, and social position determines one's identity, we might say that proportionality takes on different proportions. Acting in the name of honor is virtuous-appearances matter-but only if self-control is maintained and that society's honor code is followed. As at least some of us moderns concede, such conduct is not pathological.

I have already suggested that a sense of proportion (or balance: think Aristotle) figures differently in virtue ethics. The cardinal virtues must be in held in balance, and this requires the ongoing, ever recalibrated exercise of self-control. Out of proportion/out of control prudence turns into procrastination and indecision, decorum into empty, resource-depleting ritual, justice into self-righteousness and vigilantism, courage into machismo. For every virtue a vice. I emphasize machismo, or courage where none is called for, because it is simply the most obvious of this family of failings.

Latin cultures bear witness to the excesses and attendant social costs of machismo (see Guttman 1996 for an important discussion). They are hardly the only societies where it is to be found. Just for example, the fad for extreme sports and stunts now besetting the modern world illustrate machismo run riot. National leaders are especially prone to this pathology; consider the conduct of Russia's president. We should not be surprised. What we in IR call 'international society' arose before the modern world fully emerged and continues to bear many of the features of a traditional society. 
Paternalism. Progressive modern thinkers have long coupled paternalism and authoritarianism, for example, in leadership styles. More generally assumed is the analogy between the household and society: in traditional societies, father figures rule unchallenged. We might construe the republican preference for rule by those best suited to rule as an antidote to traditional authoritarianism, but, for most liberals, hardly an adequate one. Lately, however, paternalism has earned some respectability in liberal circles as a response to modern excesses (see Sunstein 2014 for a prominent example).

In the contemporary international society, paternalism is a chronic, systemic condition, but rarely discussed as such. Drawing on a substantial literature in applied ethics, Michael Barnett (2012) has recently directed attention to 'international paternalism.' He is hardly alone; the concern with paternalism suffuses post-colonial studies, not to mention the critique of Eurocentrism (see, for example, Hobson 2012, ch. 12), and it extends to the feminist critique of patriarchy. It is also increasingly a theme among scholars investigating the ethics of international development; here David Kennedy's The Dark Side of Virtue (2005) is a landmark. While Barnett, just for example, lamented liberal 'neglect of the underlying social relations that generate the positions of superiority and inferiority and a sense of noblesse oblige' (2012, p. 49), he had nothing to say about virtue ethics or republican theory and its affirmative sense of what noblesse oblige involves as an ethical matter.

It would seem that paternalism is generally a pejorative term for an integral feature of virtue ethics, which is, after all, predicated on societal status-ordering. As such, it offends liberal sensibilities. Nevertheless, recent concern for responsibility in the relations of states suggests an awareness that circumstances warrant some measure of paternalism. Principle 7 of the Rio Declaration on Environment and Development, issued by the United Nations Conference on Environment and Development (3-14 June 1992, A/CONF.151/26, Vol. 1, Annex 1) offers a conspicuous example.

States shall cooperate in a spirit of global partnership to conserve, protect and restore the health and integrity of the Earth's ecosystem. In view of the different contributions to global environmental degradation, States have common but differentiated responsibilities. The developed countries acknowledge the responsibility that they bear in the international pursuit to sustainable development in view of the pressures their societies place on the global environment and of the technologies and financial resources they command.

Much discussed, the principle of common but differentiated responsibilities is nonetheless overshadowed by the UN initiative and alleged new norm called 'responsibility to protect' (R2P). States are said to have primary responsibility, notably through the Security Council, but 'the international community' acting through global civil society 'should, as appropriate, encourage or assist states to exercise this responsibility' (World Summit Outcome, 2005, \$ 138). More plausibly, R2P is a continuing manifestation of the republican idea of guardian or trustee, an 
office linked to status. The guardian is a stand-in father, manifest in an executive organ acting on behalf of 'the international community' as a status-order.

On the evidence of a recent book titled Special Responsibilities: Global Problems and American Power (Bukovansky et al. 2012), some IR scholars have started to evaluated US hegemony as a matter of 'special responsibilities,' that is, responsibilities that are differentiated by reference to an asymmetric distribution of power (pp. 6-7). Needless to say, this is a familiar concern: the great powers have always been said to have great responsibilities, and the post-Vienna Concert system merely formalized the status-order warranting this state of affairs.

We might conclude, then, that paternalism is perhaps a pathology from a liberal point of view, but that the appropriate exercise of responsibility is not. The term appropriate indicates the continuing relevance of virtue ethics. As we slip into the next world, we may expect an increase in need and calls for help. Whether this will eventuate in an increased sense of responsibility among those corporate entities (states, social movements) in a position to help will surely depend on how fast things go bad.

Infantilization. One might think that infantilization results from out-of-proportion paternalism. I identify it as a pathology in its own right both because of what I take to be its importance in the ostensibly liberal modern world and because it is so little noticed. The important exception to generalization is recognition of infantilization as an effective technique for colonial administration: treat natives as children and they will act like children, unable to care for their basic needs and properly dependent on their colonial masters. (See Mehta 1997 on the liberal rationale for this technique.) The contemporary practice of treating African states as 'quasi-sovereign' tells us that infantilization persists in postcolonial settings (Jackson 1990).

More germane perhaps is infantilization in 'advanced industrial societies.' This condition and its pathological effects are notably evident in Japan. There the cult of the 'cute' (kawaii) and the pervasiveness of an imbecilic youth culture in an ageing society constantly assaults the visitor's sensibilities. Why don't those kids just grow up?

The obvious if incomplete answer is that infantilization serves an important social function. In Japan, infantilization may function to cordon off a country still deeply traditional in many respects from the many perils of modernity in its organizational mode. While Japan may be a special case, infantilization is easy enough to identify in other modern, and ostensibly liberal, societies (where Japanese youth culture is widely emulated). Privileged members of a liberal society given to excesses of various kinds are increasingly committed to protecting their children from a world that is growing harsher by the year. And not just children. Arguably the events of 11 September 2001 infantilized everyone in the U.S. As a character in a Thomas Pynchon novel says:

Can't you feel it, how everybody's regressing? 11 September infantilized this country. It had a chance to grow up, instead it chose to default back to childhood (Pynchon 2013, p. 336) 
Good conduct takes hard work; no ethical system can make it easy. Children can only learn how to exercise self-control and balance the cardinal virtues by being exposed to the world, however harsh it has become. Indeed they risk never learning, thereby becoming dependent on others for the rest of their lives. To exempt people (groups, states) from assuming a position in any society's status-order can only be construed as irresponsible. As this world slips into the next, no good can come from such a practice.

\section{References}

Barnett, Michael (2012) 'International Paternalism and Humanitarian Governance,' Global Constitutionalism, vol. 1, pp. 485-521.

Bukovansky, Mlada, et al. (2012) Special Responsibilities: Global Problems and American Power (Cambridge: Cambridge University Press).

Cappon, Lester J. (ed.) (1959) The Adams-Jefferson Letters (Chapel Hill: University of North Carolina Press).

Cicero (1991) On Duties, trans. Margaret Atkins (Cambridge: Cambridge University Press). Fei Xiaotong (1992) From the Soil: The Foundations of Chinese Society, trans. Gary G,. Hamilton and Wang Zheng (Berkeley: University of California Press).

Foucault, Michel (2007) Security, Territory, Population: Lectures at the Collège de France, 1977-1978, trans. Graham Burchill (Basingstoke: Palgrave Macmillan).

Gutmann, Matthew C. (1996) The Meanings of Macho: Being a Man in Mexico City (Berkeley: University of California Press).

Hobson John, M. (2012) The Eurocentric Conception of World Politics: Western International Theory, 1760-2010 (Cambridge: Cambridge University Press).

Jackson, Robert H. (1990) Quasi-States: Sovereignty, International Relations and the Third World (Cambridge: Cambridge University Press).

Kelsen, Hans (1961) General Theory of Law and the State, trans. Anders Wedberg (New York: Russell \& Russell).

Kennedy, David (2005) The Dark Side of Virtue (Princeton: Princeton University Press).

Machiavelli, Niccolò (1998) The Prince, trans. Harvey C. Mansfield, 2nd ed. (Chicago: University of Chicago Press).

Mehta, Uday S. (1990) 'Liberal Strategies of Exclusion,' Politics \& Society, vol. 18, pp. 427-454. Mitrany, David (1966) A Working Peace System (Chicago: Quadrangle Books).

Onuf, Nicholas (1984) 'Prometheus Prostrate,' Futures, Vol. 16, pp. 47-59.

Onuf, Nicholas (1989) World of Our Making: Rules and Rule in Social Theory and International Relations (Columbia: University of South Carolina Press).

Onuf, Nicholas (1998a) 'Everyday Ethics in International Relations,' Millennium: Journal of International Studies, Vol. 27, pp. 669-693. 
Onuf, Nicholas (1998b) The Republican Legacy in International Thought (Cambridge: Cambridge University Press).

Onuf, Nicholas (2005) 'Late Modern Civil Society,' in Randall Germain and Michael Kenny, eds., The Idea of Global Civil Society: Politics and Ethics in a Globalizing Era (London: Routledge), pp. 47-63.

Onuf, Nicholas (2013a) 'Recognition and the Constitution of Epochal Change,' International Relations, Vol. 27, pp. 121-40.

Onuf, Nicholas (2013b) 'Relative Strangers: Reflections on Hospitality, Social Distance, and Diplomacy,' in Gideon Baker, ed., On Hospitality and World Politics (Basingstoke: Palgrave Macmillan), pp. 173-96.

Onuf, Nicholas (2013c) 'Organizing for Good: Republican Theory in a Changing World,' The Global Community: Yearbook of International Law and Jurisprudence 2013, pp. 507-533.

Pettit, Philip (1997) Republicanism: A Theory of Freedom and Government (Oxford: Oxford University Press).

Pynchon, Thomas (2013) Bleeding Edge (New York: Penguin).

Skinner, Quentin (1998) Liberty before Liberalism (Cambridge: Cambridge University Press).

Smith, Adam (1984) The Theory of Moral Sentiments (Indianapolis: Liberty Fund).

Sunstein, Cass R. (2014) Why Nudge? The Politics of Libertarian Paternalism (New Haven: Yale University Press).

Weber, Max (1930) The Protestant Ethic and the Spirit of Capitalism, trans. Talcott Parsons (New York: Scribner's). 